УДК 634.11:663.293:663.1:653

(C) 2015

Яновський Ю. П., доктор сільськогосподарських наук,

Суханов С. В., кандидат біологічних наук,

Гричанюк В. П., аспірант

(науковий керівник - доктор сільськогосподарських наук Ю. П. Яновський)

Уманський національний університет садівництва

\title{
ОСОБЛИВОСТІ БІОЛОГІЇ ТА ШКІДЛИВОСТІ ВІЧКОВОЇ ГАЛИЦІ (THOMASINIANA OCULIPERDA RUBS.) I ЗАХИСТ ВIД НЕЇ САДЖАНЦІВ ЯБЛУНІ В РОЗСАДНИКУ ЛІСОСТЕПУ УКРАЇНИ
}

\section{Рецензент - доктор сільськогосподарських наук В. П. Карпенко}

Наведено результати досліджень з уточнення біологічних особливостей вічкової галиці (Thomasiniana oculiperda Rubs.) у розсаднику яблуні в зоні Лісостепу України. Встановлено, щзо зимують личинки в грунті на глибині 4-5 см, відродження яких спостерігається в кінці першоӥ-на початку другої декади квітня, а залялькування - в кінці другої - на початку третьої декади квітня. Літ дорослих самок відбувається у другій половині травня - першій половині червня. Через 8-10 днів з'являються личинки, які пошкоджують 29,8-37,7\% защеплених бруньок («вічок»). За вегетаиіииний період шкідник розвивається у трьох поколіннях. Для розвитку одного покоління шкідника необхідна сума ефективних температур від $274,3^{\circ} \mathrm{C}$ до $290,6{ }^{\circ} \mathrm{C}$ (нижній поріг складає $15,6^{\circ} \mathrm{C}$ ). Вивчено технічну ефективність застосування препаратів у захисті ичієї культури від шкідника. Встановлено, щуо для зниження ї̈ икідливості необхідно застосовувати інсектициди «Моспілан», РП (0,2 кг/2а), «Каліпсо» 480 $S C, K C(0,25 \pi / 2 a)$, «Сумітіон», $K E(2,5 \pi / 2 a)$, «Гловіс», СК (1,5 л/га), "Дурсбан» 480, к.е. (2,0 л/га), «3олон» 35, к.е. (3,0 л/га), «Ланнат» 20, РК (1,2 л/га) ma «Пірінекс» 480, KE (2,0 л/га).

Ключові слова: біологія, икідливість, вічкова галиия, рослина, шкідник, фітофаг, яблуня, саджаниі, плодовий розсадник, препарати, технічна ефективність.

Постановка проблеми. Садівництво в Україні є високоприбутковою галуззю сільського господарства, важливою складовою інтенсифікації якого є закладання високоврожайних промислових насаджень $[1,6]$. Для забезпечення потреби населення України в плодах зерняткових культур у межах науково-обгрунтованих норм ї споживання площа насаджень яблуні в 2025 р. має становити 144,8 тис. га, що потребує закладання нових садів щорічно на площі близько 10 тис. га та виробництва садивного матеріалу в межах 6,5 млн штук [5].

У розсадниках зерняткових культур в умовах
Лісостепу України зареєстровано близько 70 шкідливих комах і кліщів, які завдають значних збитків. За відсутності чи несвоєчасного виконання захисних заходів проти шкідливих об'єктів у плодових розсадниках вихід стандартних саджанців знижується на 18-33 \% $[2,3,14]$.

Вічкова галиця (Thomasiniana oculiperda Rubs.) $\epsilon$ постійним видом у розсадниках яблуні $[2,3,14]$. Останнім часом спостерігається підвищення іiі чисельності та шкідливості $[1,15,16]$, що пояснюється, в першу чергу, змінами в технології вирощування садивного матеріалу, клімату, асортименту сучасних інсектицидів та іншими чинниками [14].

Цей шкідник завдає значних збитків у плодових розсадниках, викликаючи загибель $22-40 \%$ щеплених бруньок [2, 3].

Аналіз останніх досліджень і публікацій, у яких започатковано розв'язання проблеми. На сьогодні спалах чисельності цього виду, як і багатьох інших представників ряду Двокрилих (Diptera), можна пояснити значним впливом абіотичних чинників, змінами у вирощуванні садивного матеріалу, діяльністю людини та іншим $[12,14]$.

Заходи щодо зниження шкідливості цього виду в ценозі промислових розсадників, розроблені ще в кінці минулого століття $[1,3,11]$, на сьогодні $\epsilon$ неможливими, оскільки рекомендовані інсектициди $є$ відсутніми в чинному національному «Переліку...» [10], а такий рекомендований спосіб зниження чисельності шкідника, як обгортання окулянтів грунтом після окулірування (вічкування) на сьогодні виключений, він не є однією зі складових сучасної технології вирощування саджанців зерняткових культур, зокрема яблуні.

Це пояснюється, в першу чергу, змінами у видовому складі підщепного матеріалу, який використовують сьогодні вітчизняні садоводи. Адже цей спосіб був ефективним ще чверть століття тому, коли більше $80 \%$ підщепного матеріалу слугувала сильноросла підщепа (сіянці Антонівки 


\section{СІЛЬСЬКЕ ГОСПОДАРСТВО. РОСЛИННИЦТВО}

звичайної, Грушовки московської та культурних зимостійких сортів). Тоді окультурення цієї підщепи способом вічкування (окулірування) проводилося на висоті не вище 5 см, крім того для попередження підсихання бруньки («вічка») у зв'язку з дефіцитом вологи в цей період вегетації (кінець липня - серпень) проводили обгортання грунтом таких рослин. Такий агротехнічний захід не тільки попереджував підсихання «вічок» (в першу чергу під час відсутності поливу розсадника в цей період), він знижував інтенсивність відкладання яєць в місця щеплення та пошкодження їх цим небезпечним об'єктом $[2,3]$.

На сьогодні садоводи використовують в більшості карликову підщепу М 9 і напівкарликові підщепи (54-118, 62-396, ММ 106), а вічкування роблять на висоті близько 15 см [12, 13], що виключає обгортання грунтом рослин після їх окулірування (вічкування).

Найбільш ефективним і економічно доцільним $€$ хімічний метод зниження шкідливості цього небезпечного виду в плодовому розсаднику $[3,14]$. Наразі в чинному національному «Переліку...» [10] з числа дозволених препаратів для застосування в розсадниках такі інсектициди відсутні.

У зв'язку з цим нами було прийнято рішення щодо проведення досліджень 3 визначення ефективності застосування інсектицидів 3-поміж сучасного асортименту пестицидів проти вічкової галиці в розсаднику яблуні з урахуванням біологічних особливостей іiі розвитку під час впливу погодних умов в умовах сьогоднішнього вирощування саджанців цієї культури.

Мета досліджень - уточнення біологічних особливостей розвитку вічкової галиці та розробка високоефективних заходів для зниження іiі шкідливості в промисловому розсаднику яблуні.

Завдання: удосконалити захист саджанців яблуні в розсаднику від вічкової галиці, як складової сучасної технології виробництва садивного матеріалу.

Матеріал і методика досліджень. Дослідження проводили впродовж 2010-2014 pр. в умовах плодового розсадника дослідного господарства Інституту помології ім. Л. П. Симиренка НААН України.

Методики досліджень - прийняті в агрономії для закладання польових дослідів $[4,8]$ та ентомології $[7,9]$. В полі розсадника - саджанці яблуні другого року вирощування, отримані способом вічкування. Підщепа - ММ 106. Сорти яблуні літнього, осіннього та зимового строків достигання (Папіровка, Слава Переможцям, Ренет Симиренка). Рослини висаджені в ряд. Схема садіння - 0,9х0,3 м. Облікових рослин у кожному з варіантів - 25 штук. Розмір дослідних ділянок $-100 \mathrm{~m}^{2}$. Варіанти досліду розміщені за схемою рендомізованих блоків. Площа виробничої ділянки - 1 гектар.

Упродовж вегетації доглядали за саджанцями в розсаднику за загальноприйнятими агротехнічними технологіями $[11,12]$.

Екологічні особливості і господарське значення шкідника вивчали в природних умовах агроценозу розсадника яблуні, а також за постановки лабораторно-польових дослідів.

Динаміку чисельності фітофага і пошкодження ними рослин визначали методом регулярних обліків на постійних контрольних рослинах, розташованих рівномірно в дослідних насадженнях. Крім того, щорічно проводили осінні й весняні обстеження щільності шкідника в насадженнях перед зимівлею і виживанням його після зимівлі.

Особливості біології, шкідливості фітофага вивчали в інсектарії кафедри захисту і карантину рослин Уманського національного університету садівництва на основі лабораторних дослідів. Для цього провадили ентомологічний збір об'єкта, який підсаджували в ентомологічні садки, де вивчали його шкідливість та особливості біології. Приживання «вічок» обліковували через 30 днів після проведення щеплення згідно з ДСТУ [13].

Середню заселеність шкідником рослин (личинками) в полі вирощування саджанців вираховували способом огляду 100 облікових саджанців (бруньок) в кожному з варіантів. За вивчення технічної ефективності застосування хімічних засобів захисту рослин у розсаднику рослини обробляли ранцевим обприскувачем «Універсал2» (І декада серпня) за схемою:

1. Контроль (без внесення інсектициду).

2. «Еталон» (Актеллік 500 ЕС, КЕ, 1,5л/га).

3. «Моспілан», РП - 0,2 кг/га.

4. «Каліпсо» 480 SC, КС - 0,25 л/га.

5. «Гловіс», СК - 1,5 л/га.

6. «Сумітіон», КЕ - 2,5 л/га.

7. «Пірінекс» 480, КЕ - 2,0 л/га.

8. «Дурсбан» 480 , к.е. $-2,0$ л/га.

9. «Золон» 35, к.е. $-3,0$ л/га.

10. «Ланнат» 20, РК - 1,2 л/га.

Чисельність личинок шкідника підраховували до обробки та на 10-й день після обробки з урахуванням гідротермічних умов. Розрахунок технічної ефективності застосування випробовуваних інсектицидів за формулою Аббота [7]:

$$
E \partial=\frac{100(A-B)}{A},
$$




\section{СІЛЬСЬКЕ ГОСПОДАРСТВО. РОСЛИННИЦТВО}

де: $E \partial$ - ефективність застосування препарату, \% ;

А - щільність комах (личинок) до обробки, екз./рослину;

В - щільність комах (личинок) після обробки, екз. /рослину.

Норми витрати препаратів були встановлені під час попередніх дрібноділянкових дослідів.

Грунт на ділянці - чорнозем пилуватосуглинистий на карбонатному лесі (вміст гумусу - $3 \%$; pH - 5,9; вміст рухомих сполук фосфору і калію (за методом Чирикова) - відповідно 181 мг/кг i $94 \mathrm{мг/кг} \mathrm{).}$

Сівозміна плодового розсадника була такою: чорний пар, перше поле розсадника - підщепи (в кінці липня - на початку серпня проводили вічкування), друге поле розсадника - однорічки (в кінці сезону - саджанці встановленого стандарту), третє поле розсадника - дворічки (саджанці встановленого стандарту), ячмінь 3 підсівом багаторічних трав, багаторічні трави.

Погодні умови за період досліджень були сприятливими для вирощування саджанців в розсаднику яблуні та розвитку на них шкідливої ентомофауни. Математичну обробку даних здійснювали $з$ використанням комп'ютера та робочої програми «Статистика» методом дисперсійного аналізу [7, 9].

Результати досліджень. Встановлено, що зимують личинки в грунті на глибині 4-5 см, відродження яких відбувалося за середньодобової температури повітря $+11,3-12,8^{\circ} \mathrm{C}$ та середній вологості повітря 78,3-84,7\% наприкінці I-на початку II декади квітня, а заляльковування наприкінці II - на початку III декади квітня. Літ дорослих особин (які розмножувалися без заплід- нення) спостерігався за середньодобової температури повітря $+15,7-17,3^{\circ} \mathrm{C}$ та середній вологості повітря 80,7-83,9 \% 3 другої половини травня (2010, 2012, 2014 роки) і тривав до другої половини червня $(2011,2013$ роки). Самиці відкладали по 2-3 яйця на поверхню кори в місцях щеплення «вічком», яке було зроблено в кінці липня - середині серпня минулого року. Через 8-10 днів 3'являлися темно-червоні личинки, які проточували поздовжні ходи в деревині, щепленій бруньці, від чого окулянти всихали.

Результати досліджень свідчать, що строки проведення вічкування (кінець липня - початок серпня - середина серпня) не мали вирішального значення на строки відкладання яєць шкідником i ïx чисельності. Швидше строки проведення цієї операції по отриманню саджанців впливають на приживання «вічок», що тотожно думці В. I. Майдебури та інших [11].

Появу дорослих імаго першого покоління було зафіксовано в другій декаді липня, літ особин шкідника тривав два (2010, 2012, 2014 рр.) - три тижні (2011, 2013 pp.).

Літ особин третього покоління тривав 3 початку і до кінця серпня. Відроджені личинки після закінчення живлення (з кінця другої декади жовтня) і до початку зниження температури повітря (нижче $+10^{\circ} \mathrm{C}$ ) ховалися в грунт на зимівлю.

В результаті отриманих даних встановлено, що для розвитку одного покоління шкідника необхідна сума ефективних температур від $274,3{ }^{\circ} \mathrm{C}$ до $290,6^{\circ} \mathrm{C}$ (нижній поріг розвитку складає $\left.15,6^{\circ} \mathrm{C}\right)$.

Технічна ефективність застосування інсектицидів проти вічкової галиці в розсаднику яблуні (ДГ Інституту помологї ім. Л. П. Симиренка НААН Украӥни, середнє за 2010-2014 рр.)

\begin{tabular}{|c|c|c|c|c|}
\hline \multirow{3}{*}{$\begin{array}{c}\text { Варіант } \\
\text { (препарат, норма його витрати } \\
\text { на гектар ) }\end{array}$} & \multicolumn{3}{|c|}{ Ефективність застосування, \% } & \multirow{3}{*}{$\begin{array}{c}\text { Пошкод- } \\
\text { жено } \\
\text { «вічок», \% }\end{array}$} \\
\hline & \multicolumn{3}{|c|}{ сорти } & \\
\hline & Папіровка & $\begin{array}{c}\text { Слава } \\
\text { Переможцям }\end{array}$ & $\begin{array}{c}\text { Ренет } \\
\text { Симиренка }\end{array}$ & \\
\hline Контроль (без внесення інсектициду) & 0,0 & 0,0 & 0,0 & 33,8 \\
\hline «Актеллік» 500 EC, КЕ, 1,5 л/га (еталон) & 89,7 & 88,9 & 91,2 & 4,0 \\
\hline «Моспілан», РП, 0,2 кг/га & 93,9 & 94,3 & 95,9 & 1,0 \\
\hline «Каліпсо» 480 SC, КС, 0,25 л/га & 94,7 & 93,8 & 92,8 & 1,0 \\
\hline «Гловіс», СК, 1,5 л/га & 93,1 & 91,6 & 93,7 & 2,0 \\
\hline «Сумітіон», КЕ, 2,5 л/га & 94,8 & 92,3 & 94,1 & 2,0 \\
\hline «Пірінекс» 480, КЕ, 2,0 л/га & 91,3 & 93,8 & 92,3 & 2,0 \\
\hline «Дурсбан» 480, к.е., 2,0 л/га & 91,9 & 91,1 & 94,2 & 2,0 \\
\hline «Золон» 35, к.е., 3,0 л/га & 91,4 & 92,8 & 91,2 & 2,0 \\
\hline 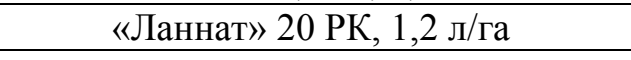 & 93,2 & 93,4 & 93,5 & 1,0 \\
\hline $\mathrm{HIP}_{05}$ & 0,1 & 0,1 & 0,1 & 0,1 \\
\hline
\end{tabular}




\section{СІЛЬСЬКЕ ГОСПОДАРСТВО. РОСЛИННИЦТВО}

Результати досліджень свідчать, що від пошкодження цим фітофагом, за відсутності проведення захисних заходів, загибель щеплених бруньок («вічок») на саджанцях яблуні складає 29,8-37,7\%.

Таким чином, вічкова галиця $є$ постійним i шкідливим видом в агробіоценозі розсадника яблуні і розвивається впродовж вегетації в трьох поколіннях.

Результати досліджень свідчать, що ефективним заходом для зниження шкідливості галиці є обприскування інсектицидами вегетуючих рослин яблуні в розсаднику (див. табл.).

Так, вже на на 10-й день після обприскування ефективність застосування препаратів «Моспілан», РП (0,2 кг/га), «Каліпсо» $480 \mathrm{SC}, \mathrm{KC}(0,25$ л/га), «Гловіс», СК (1,5 л/га), «Сумітіон», КЕ (2,5 л/га), «Пірінекс» 480, КЕ (2,0 л/га), «Дурсбан» 480 , к.е. (2,0 л/га), «Золон» 35, к.е. (3,0 л/га) та «Ланнат» 20, РК (1,2 л/га) становила 91,194,8 \%, що не поступалося еталонному препарату «Актеллік» 500 ЕС, КЕ (1,5 л/га).

Пошкодження «вічок» (щитка 3 брунькою) під час застосування цих препаратів не перевищувало 1,0-2,0 \% (за 33,8 \% на контролі).

\section{БІБЛІОГРАФІЯ}

1. Воєводін B. В. Садівництво України, сьогодення і майбутнє / В. В. Воєводін // Сад, виноград і вино України. - 2001. - №12. - С. 2-5.

2. Вредители сельскохозяйственных культур и лесных насаждений в 3 т. : [под ред. В. П. Васильева]. - К. : Урожай, 1987. - Т.2 [«Вредные членистоногие, позвоночные»]. - 490 с.

3. Довідник по захисту садів від шкідників i хвороб / [Матвієвський О. С., Каленич Ф. С., Лошицький В. П., Ткачов В. П.]. - К. : Урожай, 1990. -215 c.

4. Єщенко В. О. Основи наукових досліджень в агрономії : [підруч. для студ. вищ. навч. закл.] / В. О. Сщенко, П. Г. Копитко, П. В. Костогриз. К. : Дія, 2005. - 186 с.

5. Костенко В. М. Шляхи розвитку вітчизняного садівництва у новій ситуації. Що маємо на сьогодні і що слід зробити для вирішення існуючих проблем галузі / В. М. Костенко // Сад, виноград і вино України. - 2009. - №7-9. - С. 5-10.

6. Куян В.Г. Спеціальне плодівництво / В. Г. Куян. - К. : Світ, 2004. - 464 с.

7. Методики випробування і застосування пестицидів / [ Трибель С. О., Сігарьова Д. Д., Секун М. П. та ін.] ; під ред. С. О. Трибеля - К. : Світ, 2001. $448 \mathrm{c}$.

8. Мойсейченко $B$. Ф. Методика опытного дела
Висновок. Результати наших досліджень дають можливість стверджувати, що вічкова галиця (Thomasiniana oculiperda Rubs.) є постійним видом у розсадниках яблуні. Від пошкодження цим фітофагом за відсутності проведення захисних заходів загибель щеплених бруньок («вічок») на саджанцях складає 27,9-41,3\%.

Тож, захист рослин від неї має бути складовою частиною сучасної технології вирощування саджанців у промислових розсадниках яблуні.

Встановлено, що ефективним заходом для зниження шкідливості вічкової галиці є обприскування інсектицидами вегетуючих рослин яблуні в розсаднику.

У зв'язку з цим необхідно порушити питання перед Департаментом екологічної безпеки Міністерства екології та природних ресурсів України про подальші дослідження по ефективності застосування препаратів «Моспілан», РП (0,2 кг/га), «Каліпсо» $480 \mathrm{SC}, \mathrm{KC} \mathrm{(0,25} \mathrm{л/га),} \mathrm{«Гло-}$ віс», СК (1,5 л/га), «Сумітіон», КЕ (2,5 л/га), «Пірінекс» 480, КЕ (2,0 л/га), «Дурсбан» 480, к.е. (2,0 л/га), «Золон» 35, к.е.(3,0 л/га) та «Ланнат» 20, РК(1,2 л/га) та їх реєстрації у боротьбі з вічковою галицею в промислових розсадниках яблуні.

в плодоводстве и овощеводстве / В. Ф. Мойсейченко. - К. : Вища школа, 1988. - С. 73-88.

9. Облік шкідників і хвороб сільськогосподарських культур / [В. П. Омелюта, І. В. Григорович, В. С. Чабан та ін.] ; під ред. В. П. Омелюти. - К. : Урожай, 1986. - 2005. - С. 23-243.

10. Перелік пестицидів і агрохімікатів, дозволених до використання в Україні: за станом на 23 травня 2014 р. - офіц. вид. - К. : Юнівест Медіа, 2014. - 832 с. - (Документ Департаменту екологічної безпеки Міністерства охорони навколишнього природного середовища України).

11. Рекомендации по выращиванию плодовых саженцев в Украинской ССР / [В. И. Майдебура, В. М. Васюта, И. М. Мережко, В.В.Бурковский и др.]. - К., 1983. - С. 16-20.

12. Poccoxa E. B. Все начинается с саженца/ Е. В. Россоха, В. И. Афанасьева // Сад, виноград і вино України. - 2002. - №9-10. - С. 11-12.

13. Саджанці плодових культур. Технічні умови : ДСТУ 4938:2008. - [Чинний від 2008.03.26]. - К. : Держспоживстандарт України, 2009. - 11 с. - (Національний стандарт України).

14. Яновський Ю. П. Основні шкідники зерняткових у розсадниках і захист рослин від них у Лісостепу України / Ю. П. Яновський. - Корсунь-Шевченківський : Ірена, 2002. - 299 с. 